\title{
Improving Soya Bean Productivity for Poverty Alleviation and Food Security in Upper West Region of Ghana: A Resource Use Efficiency Analysis
}

\author{
Francis Akabo Asodina, Faizal Adams, Fred Nimoh, Camillus Abawiera Wongnaa*, Robert Aidoo \\ and Kwasi Ohene-Yankyera \\ Department of Agricultural Economics, Agribusiness and Extension, Kwame Nkrumah University of \\ Science and Technology Kumasi, Ghana \\ *Corresponding author: wongnaaa@yahoo.com
}

\begin{abstract}
Soya bean is an important economic crop for smallholder farming systems in Upper West Region of Ghana. In spite of the introduction of modern and improved soya bean production technologies in Ghana, the productivity of the crop in the region is still low. Given that inefficient use of resources is a potential course of low yields, this study analyses the resource use efficiency of soya bean production. Using cross-sectional data collected from 271 soya bean farmers from the Upper West Region of Ghana, the study employed the Stochastic Frontier Translog Production Function as well as the ratio of Marginal Value Product to Marginal Factor Cost to understand the resource use efficiency of soya bean farmers in the region. The empirical results showed that the estimated coefficients of soya bean seeds, labor and farm size were significant and positively related to soya bean output even though fertilizer input was surprisingly significantly and negatively related to the output of soya bean. Also, resources employed in soya bean production were found not to be efficiently utilized as they were underutilized, indicating that yield and profit could be improved with optimal use of production inputs. Finally, the paper revealed that access to soya bean threshers is the most important constraint faced by farmers in the region. For the region's soya bean yield to be improved, government and development organizations should assist soya bean farmers by removing major bottlenecks to acquisition of resources required for the production and postharvest handling of the crop.
\end{abstract}

Keywords: resource acquisition; stochastic frontier; threshers; underutilized and yield

Cite this as: Asodina, F. A., Adams, F., Nimoh, F., Wongnaa, C. A., Aidoo, R., \& Ohene-Yankyera, K. (2021). Improving Soya Bean Productivity for Poverty Alleviation and Food Security in Upper West Region of Ghana: A Resource Use Efficiency Analysis. Caraka Tani: Journal of Sustainable Agriculture, 36(1), 175-187. doi: http://dx.doi.org/10.20961/carakatani.v36i1.44311

\section{INTRODUCTION}

In Sub-Saharan Africa (SSA), concerns to increase smallholder crop productivity have received considerable attention among governments and agricultural administrators, especially in Ghana. Ghana's agriculture is dominated by smallholder farmers cultivating less than 2 hectares of farmland (Awunyo-vitor et al., 2013). These farmers rely on the conventional technology of cutlass and hoe but are responsible for about two thirds of the national food supply in the country (Ansah et al., 2016; Khalid and Sherzad, 2019. As a result, yields for major food crops such as cereals and legumes in the country have stagnated below $15 \%$ growth rate while per capita food production has experienced constant decline over the past 20 years in the country (FAOSTAT, 2018). The low crop yield problem in Ghana and other

\footnotetext{
* Received for publication September 12, 2020

Accepted after corrections February 20, 2021
} 
parts of Sub-Saharan Africa has largely been attributed to inefficient use of limited resources (Fasasi, 2006; Tambo and Gbemu, 2010; Wongnaa and Ofori, 2012; Goni et al., 2013; Awunyo-Vitor et al., 2016). Such poor crop performance, particularly legumes, including soya bean, has led to chronic food insecurity, poverty and malnutrition in larger parts of Ghana, particularly Upper West region, where more than $80 \%$ of the population depend on smallholder farming systems for sustenance and livelihoods (Al-hassan and Diao, 2007).

Upper West region is the most povertystricken region of Ghana with 7 out of every 10 persons being poor, while $30 \%$ of the population is food insecure and additional $60 \%$ is vulnerable to food insecurity (Aryeetey and Mckay, 2004). The region has an agrarian economy with more than $60 \%$ smallholder farmers who cultivate soya bean for livelihoods and sustenance (SRID, 2013). Soya bean (Glycine $\max \mathrm{L})$ represents a major economic crop in smallholder farming systems because the crop has the capacity to sustain soil fertility through atmospheric and Biological Nitrogen Fixation (BNF) (Mpepereki et al., 2000; Chianu et al., 2009), provides crop by-product for livestock feed and improves rural household nutrition and income. According to Giller et al. (2011), strong rotational benefits were observed for maize and soya bean as the crop broke the cycle of continuous maize cultivation and fixed nitrogen to the soil. Benefits received from Symbiotic Nitrogen Fixation support build sustainable soil fertility systems and profitability for smallholder farmers. Moreover, the substitution of Nitrogen fertilizer in soya bean-maize rotations aids in reducing Carbon emissions for sustainable agricultural production.

In an attempt to stimulate domestic soya bean production for food security and poverty reduction among farmers in Upper West region, crop administrators and rural development practitioners have placed emphasis on the introduction of modern and improved technologies and abstracts from efficient use of existing resources for production (Dogbe et al., 2013). This is because soya bean productivity is low and below potential levels, despite the favorable agro-ecological zone of the area (MoFA, 2011). For instance, the $194 \mathrm{~kg} \mathrm{ha}^{-1}$ soya bean yield observed in the region is the lowest in Ghana and also about $80 \%$ below the average yield (348 kg ha-1) for neighboring Northern region (Amanor-Boadu et al., 2015).

Information on the resource use efficiency in soya bean production is scanty (Mugabo et al., 2014; Upev et al., 2016; Amaechina and Eboh, 2017) but common for other crops such as cereals and tubers (Majumder et al., 2009; Sani et al., 2010; Nimoh et al., 2012; Maikasuwa and Ala, 2013; Tirlapur and Mundinamani, 2015; Awunyo-Vitor et al., 2016). For instance, Awunyo-Vitor et al. (2016) used the Translog functional form to estimate the resource use efficiency levels of maize farmers in Ghana. The empirical results show that the quantities of fertilizer, herbicides, pesticides, seed and land were underutilized while capital and labor were overutilized. The study concludes that incentives and strategies that encourage farmers to apply more fertilizer, herbicides, pesticides, seeds and expand cultivated land must be made a priority for optimum resource utilization among maize farmers.

In a related study, Nimoh et al. (2012) examined the irrigated rice farmers in the Dangme West district of Ghana, employed the CobbDouglas functional form and observed that land and seed were underutilized while labor and chemicals were overutilized. A study on small-scale irrigation farms in Bunkure Local Government area of Kano State, Nigeria conducted by Sani et al. (2010) show that fertilizer and land were underutilized and must be increased for optimum input utilization. In this study, the Cobb-Douglas model best fits the data compared with the traditional Ordinary Least Square (OLS) regression model. Amaechina and Eboh (2017) also studied rice farmers' resource efficient allocation in Nigeria. The authors reported an imbalance in the allocation of major resources such as land, seed, fertilizer, chemicals and labor. All the resources except cultivated farmland were underutilized. The inefficiency was due to high production costs.

For the few studies on resource efficiency of soya bean farmers especially for developing economies, Mugabo et al. (2014) in Rwanda concluded that the key production inputs such as farm size, fertilizers and pesticides were underutilized. Similarly, Upev et al. (2016) from Gboko Local Government Area of Benue State, Nigeria also found that seed, farm size, herbicide and fertilizer for soya bean production were underutilized except labor which was over 
utilized. In support of this finding, Obasi et al. (2000) in same study area also observed that the farm size, labor, tractor use and chemicals were underutilized and recommended that these inputs should be increased for optimum utilization.

Generally, empirical studies on resource use efficiency of soya bean farmers in Ghana, particularly the Upper West region are limited (Awunyo-Vitor et al., 2016), hence it is very important to examine the efficiency of resource use for soya bean production in Upper West region of Ghana. The use of the stochastic frontier in this study follows Awunyo-Vitor et al. (2016) for maize farmers in Ghana. Information from the study will contribute to literature; guide farmers, crop administrators and policymakers on how to adjust the use of key inputs to maximize output, minimize waste and also save cost. The study, therefore, focuses on examining the resource use efficiency for soya bean production in Upper West region of Ghana.

\section{MATERIALS AND METHOD}

\section{Data}

The study was conducted in the Upper West region of Ghana in three soya bean producing districts, viz. Sissala West, Daffiama Busie Issah (DBI) and Wa East. The region has a land area of $18,478 \mathrm{~km}^{2}$ and an average maximum rainfall of $110 \mathrm{~mm}$ with a temperature of $25-40{ }^{\circ} \mathrm{C}$. The data were collected from registered soya bean farmers for the 2016 production year. A multi-stage sampling technique was used to select 271 soybean farmers for the study. The farmers are smallholders (cultivating less than 2 hectares).

At stage one of the multi-sampling procedure, three (3) districts (Sissala West, Wa East and DBI) were purposively selected from the region based on their importance in soybean production. A simple random selection was applied at the second stage to select nine (9) communities, 3 in each district, for data collection. At stage three (3), 271 soybean farmers were selected through simple random selection. A sample frame comprising the list of soybean farmers was obtained from agricultural extension officers at each community. The list was entered into Microsoft Excel and the rand command was executed to select individual farmers based on the representative sample size from each community.
The population of farmers in the nine (9) selected communities were not equal so proportional sampling technique was used to determine the sample size of each community in the various districts. The sample size was determined using the Yamane's (1967) formula.

\section{Analytical framework}

According to Latruffe (2010), efficiency gives an indication of whether firms are able to use the existing technology in the best way. It has three components, viz. scale efficiency, technical efficiency and allocative efficiency. Scale efficiency gives insights into whether the firm operates at an optimal or sub-optimal size. Technical efficiency shows whether a firm is able to attain the maximum output from a given set of inputs. By contrast, the allocative efficiency of a firm reflects its ability to use inputs in their optimal proportions given their respective prices. A firm is allocatively efficient if its outputs and inputs maximize its profit (or minimize its costs) at given prices. Allocative efficiency implies technical efficiency, as in order to maximize its profits, the firm must firstly lie on the production frontier. However, technical efficiency does not necessarily imply allocative efficiency, since the combination of outputs and inputs can be optimal with respect to the production possibilities, but not be profit maximizing. This is the reason allocative efficiency is used in this study. Following Awunyo-Vitor et al. (2016), the allocative efficiency analysis in this study was done within the framework of the stochastic frontier production function. The stochastic frontier model (Battese and Coelli, 1995) has largely been used to examine the determinants of output in agricultural production. The model is generally defined as:

$$
\begin{gathered}
Y_{i}=f\left(X_{i} ; \beta\right) \exp \left(\varepsilon_{i}\right)=f\left(X_{i} ; \beta\right) \exp \left(V_{i}-\right. \\
\left.U_{i}\right), i=1,2, \ldots \ldots . N \quad(1)
\end{gathered}
$$

\footnotetext{
Where:

$\mathrm{Y}=$ Output

$\mathrm{X}=$ Vector of inputs

$\beta=$ Parameter estimates

$V_{i}=$ Stochastic error beyond farmer's influence

$\mathrm{U}_{\mathrm{i}}=$ Non-negative random variable

$\varepsilon_{\mathrm{i}}=$ Composed error term

$\mathrm{N}=$ Represents the number of farmers involved in the Research
} 
Technical efficiency is a quotient of observed output of a soya bean farmer to the frontier output (Battese and Coelli, 1995) and is given as:

$$
\mathrm{TE}_{\mathrm{i}}=\frac{\mathrm{Y}_{\mathrm{i}}}{\mathrm{Y}^{*}{ }_{\mathrm{i}}}=\frac{\mathrm{f}\left(\mathrm{X}_{\mathrm{i}}, \beta\right) \exp \left(\mathrm{V}_{\mathrm{i}}-\mathrm{U}_{\mathrm{i}}\right)}{\mathrm{f}\left(\mathrm{X}_{\mathrm{i}}, \beta\right) \operatorname{expV_{i}}}=\exp ^{-U_{\mathrm{i}}}
$$

Since $U_{i}$ represents random error variables accounting for technical inefficiency and is within the farmer's control, factors that affect such inefficiency are stated as:

$$
\mathrm{U}_{\mathrm{i}}=\gamma_{0}+\sum_{\mathrm{j}=1}^{\mathrm{j}} \gamma_{\mathrm{j}} \mathrm{Z}_{\mathrm{ij}}+\varepsilon
$$

Where $\gamma$ denotes parameters and $Z_{i}$ is the socioeconomic factor influencing efficiency. The variance parameters include:

$$
\begin{aligned}
& \delta^{2}=\delta^{2}{ }_{\mathrm{u}}+\delta_{\mathrm{v}}{ }^{2} \text { and } \\
& \gamma=\frac{\delta_{\mathrm{u}}{ }^{2}}{\delta \mathrm{v}}
\end{aligned}
$$

The Maximum likelihood estimation procedure was adopted to estimate the stochastic frontier production model (Awunyo-Vitor et al., 2016). Hypothesis were tested to determine the appropriate function that best fitted the data and the result indicated that the widely flexible translog production function adequately fitted the data used in this study.

Empirically, the stochastic frontier translog production function is specified as:

$$
\begin{aligned}
\ln Y= & \beta_{0}+\sum_{\mathrm{j}-1}^{\mathrm{m}} \beta_{\mathrm{j}} \ln \mathrm{X}_{\mathrm{ij}} \\
& +0.5 \sum_{\mathrm{j}-1}^{\mathrm{m}} \sum_{\mathrm{k}-1}^{\mathrm{m}} \beta_{\mathrm{jk}} \ln \mathrm{X}_{\mathrm{ij}} \ln \mathrm{X}_{\mathrm{ik}}+\mathrm{V}-\mathrm{U}
\end{aligned}
$$

Where $\mathrm{Y}$ is total quantity of output in kilogram, $X_{i}$ is a vector of inputs employed in soya bean production, $\mathrm{m}$ is number of production inputs, $i j$ is positive integer with $i \neq j, \beta^{\prime} s$ is parameter to be estimated and $\mathrm{V}$ and $\mathrm{U}$ have their usual meanings. The first-order coefficients of the input variables estimate the partial output elasticities for each input at mean input values. Consequently, the sum of the output elasticity from the input variables is the scale elasticity $(\varepsilon)$ which is defined as the degree of responsiveness of output to input changes. The inefficiency model is also specified as:

$$
\mathrm{U}=\gamma_{0}+\sum_{\mathrm{m}=1}^{\mathrm{N}} \gamma_{\mathrm{m}} \mathrm{z}_{\mathrm{i}}
$$

Where $z_{i}$ is a vector of farmer and farm characteristics and $\gamma$ is a vector of parameters to be estimated.

Kay (1981) and Shehu et al. (2017) posit that a firm maximizes its profit if its Marginal Value Product (MVP) equals Marginal Factor Cost (MFC). A ratio less than one shows overutilization of the resources and a ratio greater than one indicates underutilization of the input.

Marginal Value Productivities of the inputs are computed from the results of estimated coefficients or elasticities of the farms' production function. According to Miah et al. (2006) and Tambo and Gbemu (2010), for farmers to use resources efficiently, such resources must be used until MVP is equal to MFC under perfect competition. Therefore, the resource use efficiency parameter is calculated as:

$$
r=\frac{M V P}{M F C}
$$

where $r$ is efficiency coefficient, MVP is marginal value product and MFC is marginal factor cost of inputs.

$$
\mathrm{MFC}=\mathrm{P}_{\mathrm{xi}}
$$

where $P_{x i}$ is unit price of input, say $x$

$$
\mathrm{MVP}_{\mathrm{x}}=\mathrm{MPP}_{\mathrm{x}} \cdot \mathrm{P}_{\mathrm{y}}
$$

where $\mathrm{P}_{\mathrm{y}}=$ mean value of output, $\mathrm{MPP}_{\mathrm{x}}=$ marginal physical product of input $\mathrm{x}$,

$$
\text { If } \beta_{x}=\text { output elasticity of input. }
$$

Then from the estimated stochastic frontier translog production function,

$$
\beta_{\mathrm{x}}=\frac{\partial \operatorname{InY}}{\partial \operatorname{InX}}=\frac{\partial \mathrm{Y}}{\partial \mathrm{x}}
$$




$$
\operatorname{MPP}_{\mathrm{X}}=\frac{\partial \mathrm{Y}}{\partial \mathrm{x}} \cdot \frac{\mathrm{x}}{\mathrm{Y}}=\beta_{\mathrm{x}} \frac{\mathrm{Y}}{\mathrm{x}}
$$

Therefore,

$$
\mathrm{MVP}=\frac{\partial \mathrm{Y}}{\partial \mathrm{x}} \cdot \mathrm{P}_{\mathrm{y}}=\beta_{\mathrm{x}} \frac{\mathrm{Y}}{\mathrm{x}} \cdot \mathrm{P}_{\mathrm{y}}
$$

To decide whether or not an input was used efficiently, the following convention was followed:

$r=1$ it implies the input was used efficiently

$r>1$ it implies the input was underutilized and therefore both output and profit would be increased if more of that input was employed

$r<1$ it implies the input was over utilized and therefore both output and profit would be maximized if less of that input was employed (Ohajianya, 2006; Salisu et al., 2015)

Returns to scale was calculated by the sum of the output elasticities of the various inputs given as (Awunyo-Vitor et al., 2016):

$$
\text { Return to scale }=\sum_{\mathrm{i}} \frac{\partial \operatorname{InY}}{\partial \operatorname{In} X_{\mathrm{i}}}=\sum_{\mathrm{i}} \beta_{\mathrm{i}}
$$

where $Y$ is output, $X_{1}$ is input and $\beta_{i}$ is output elasticity. The scale of soya bean production in the study area was obtained using the following decision rule:

When $\sum \beta_{\mathrm{i}}=1$; constant returns to scale When $\sum \beta_{i}<1$; decreasing returns to scale When $\sum \beta_{\mathrm{i}}>1$; increasing returns to scale

To adjust for resource use efficiency, the percentage deviation from optimal resource use level, the percentage divergence was calculated as:

$$
\text { Percentage divergence }=\frac{\mathrm{MVP}-\mathrm{MFC}}{\mathrm{MVP}} \times 100 \%
$$

Finally, Kendell's coefficient of concordance was used to rank the constraints of soya bean farmers in the study area. The Kendell's coefficient of concordance $(W)$ was determined from the respondents' rankings as follows:

$$
\mathrm{W}=\frac{12 \sum \mathrm{T}_{\mathrm{j}}^{2}-3 \mathrm{~K}^{2} \mathrm{~N}(\mathrm{~N}+1)^{2}}{\mathrm{~K}^{2} \mathrm{~N}\left(\mathrm{~N}^{2}-1\right)}
$$

where: $T_{j}=$ Sum of ranks, $N=$ Number of variables ranked, $\mathrm{K}=$ Number soya bean farmers. The means were then ranked again to find the most pressing constraint to the least.

\section{RESULTS AND DISCUSSION}

\section{Socio-economic characteristics}

As depicted in Table 1, the majority (80\%) of the soya bean farmers are females and this justifies the cultural perception that soya bean is a 'women crop' and thus, is often dominated by female farmers. This result has implications for time and resource allocation for soya bean production, since females are socially responsible for all household chores activities; child and family upkeep and may also face constraints to productive resources such as land and capital. The result, however, contradicts the study by Oyekunle et al. (2014) that reported 25\% of soya bean farmers in Ogun State, Nigeria as females.

A large proportion of the farmers are uneducated, $69 \%$ of whom could neither read nor write and this could negatively affect agricultural information processing and technology adoption for improved productivity (Seyoum et al., 1998). The finding corroborates the $77.5 \%$ of uneducated soya bean farmers observed by Dogbe et al. (2013) in northern Ghana. Even though the major source of capital for soya bean farmers is the informal sector, specifically from Village Savings and Loans Associations (VSLA) (73\%), relatives (49\%) and friends (44\%), only $31 \%$ of the respondents obtained funds from these sources. The limitation to formal credit sources (commercial banks (4\%), microfinance (8\%) and rural banks (28\%)) may negatively affect production through innovation adoption since informal sources come with several challenges (Fasasi, 2006).

The respondents have low experience, as justified by the mean of soya bean farming experience of 4.43 years. The finding confirms the study of Dogbe et al. (2013) and Avea et al. (2016) that previously reported that the cultivation of soya bean is relatively new to Ghanaian farmers. On the other hand, large proportion $(88 \%)$ of the respondents have access to extension services with a mean visits of 22 times per production circle. Such a higher extension visit turnover is crucial for improved 
production given the high illiteracy rate (69\%) and low farming experiences among the respondents.

The study depicts an average household size of 11 persons which is similar to the observation made by Avea et al. (2016) in northern Ghana. The relatively larger household size may denote an increase in labor availability for farm and other related activities. The average respondents' age of 42 years is higher than the 36 years reported by Avea et al. (2016) but similar to the 44 years observed by Dogbe et al. (2013) in northern Ghana. The farmers' age implies youthful exuberant in soya bean production to carry out the drudgery activities of soya bean production process. Similarly, the high youthful involvement in soya bean production may infer sustainability of the crop cultivation in the area and could serve as an important employment avenue.

Table 1. Socio-economic characteristics of soya bean farmers

\begin{tabular}{|c|c|c|c|c|c|}
\hline \multirow{2}{*}{ Variables } & & \multicolumn{4}{|c|}{ Districts } \\
\hline & & \multirow{2}{*}{$\frac{\text { Sissala West }}{\mathrm{N}(\%)}$} & \multirow{2}{*}{$\begin{array}{l}\text { Wa East } \\
\mathrm{N}(\%)\end{array}$} & \multirow{2}{*}{$\begin{array}{c}\mathrm{DBI} \\
\mathrm{N}(\%)\end{array}$} & \multirow{2}{*}{$\begin{array}{l}\text { Total } \\
\mathrm{N}(\%) \\
\end{array}$} \\
\hline \multirow{3}{*}{ Sex } & & & & & \\
\hline & Male & $34(35)$ & $15(16)$ & $4(5)$ & $53(20)$ \\
\hline & Female & $64(65)$ & $79(84)$ & $75(95)$ & $218(80)$ \\
\hline \multirow[t]{3}{*}{ Marital status } & Single & $9(9)$ & $0(0)$ & $0(0)$ & $9(3)$ \\
\hline & Married & $79(81)$ & $79(84)$ & $62(78)$ & $220(82)$ \\
\hline & Widow/widower & $10(10)$ & $15(16)$ & $17(22)$ & $42(15)$ \\
\hline \multirow[t]{4}{*}{ Religion } & Christian & $3(3)$ & $15(15)$ & $46(58)$ & $64(24)$ \\
\hline & Muslim & $93(95)$ & $78(84)$ & $29(37)$ & $200(74)$ \\
\hline & $\begin{array}{l}\text { Africa traditional } \\
\text { faith }\end{array}$ & $2(2)$ & $1(1)$ & $3(4)$ & $6(2)$ \\
\hline & Others & $0(0)$ & $0(0)$ & $1(1)$ & $1(0)$ \\
\hline \multirow[t]{6}{*}{ Education } & Non-formal & $62(63)$ & $67(71)$ & $59(75)$ & $188(69)$ \\
\hline & Primary & $16(17)$ & $10(11)$ & $9(11)$ & $35(13)$ \\
\hline & Junior High & $4(4)$ & $3(3)$ & $4(5)$ & $11(4)$ \\
\hline & Senior High & $6(6)$ & $3(3)$ & $5(6)$ & $14(5)$ \\
\hline & Tertiary & $3(3)$ & $0(0)$ & $0(0)$ & $3(1)$ \\
\hline & Arabic & $7(7)$ & $11(12)$ & $2(3)$ & $20(8)$ \\
\hline \multirow{2}{*}{$\begin{array}{l}\text { Access to formal } \\
\text { Credit }\end{array}$} & Yes & $59(60)$ & $7(7)$ & $18(23)$ & $84(31)$ \\
\hline & No & $39(40)$ & $87(93)$ & $61(77)$ & $187(69)$ \\
\hline \multirow[t]{7}{*}{ Sources of credit* } & Commercial banks & $12(12)$ & $0(0)$ & $0(0)$ & $12(4)$ \\
\hline & Microfinance & $15(15)$ & $2(2)$ & $1(1)$ & $18(6)$ \\
\hline & Rural banks & $52(53)$ & $16(17)$ & $9(11)$ & $77(28)$ \\
\hline & Friends & $54(55)$ & $40(42)$ & $24(30)$ & $118(44)$ \\
\hline & Relatives & $57(58)$ & $41(44)$ & $35(44)$ & $133(49)$ \\
\hline & $\begin{array}{l}\text { Village savings and } \\
\text { loans association }\end{array}$ & $58(59)$ & $66(70)$ & $73(92)$ & 197(73) \\
\hline & Others & $17(17)$ & $6(6)$ & $1(1)$ & $24(9)$ \\
\hline Access to & Yes & $94(96)$ & $69(73)$ & $76(96)$ & $239(88)$ \\
\hline Extension service & No & $4(4)$ & $25(27)$ & $3(4)$ & $32(12)$ \\
\hline \multicolumn{2}{|c|}{ Continuous variables } & Means (Std) & Means (Std) & Means (Std) & Means (Std) \\
\hline \multicolumn{2}{|c|}{ Age } & $41.53^{\mathrm{d}}(11.69)$ & $41.89^{\mathrm{d}}(9.79)$ & $42.76^{\mathrm{d}}(9.91)$ & $42.01(10.52)$ \\
\hline \multicolumn{2}{|l|}{ Household Size } & $9^{\mathrm{a}}(3.14)$ & $12^{\mathrm{b}}(6.52)$ & $12^{\mathrm{c}}(5.48)$ & $10.90(5.48)$ \\
\hline \multicolumn{2}{|c|}{ Education (years) } & $2.67^{\mathrm{d}}(4.43)$ & $1.57^{\mathrm{d}}(2.96)$ & $2^{\mathrm{d}}(3.78)$ & $2.07(3.80)$ \\
\hline \multicolumn{2}{|c|}{ Extension (no. of visits) } & $34^{\mathrm{a}}(36.43)$ & $14^{\mathrm{b}}(13.18)$ & $14^{\mathrm{c}}(12.51)$ & $21.97(26.62)$ \\
\hline \multicolumn{2}{|c|}{ Experience (years) } & $5.07^{\mathrm{a}}(2.36)$ & $5.44^{\mathrm{b}}(3.53)$ & $2.44^{\mathrm{c}}(.73)$ & $4.43(2.85)$ \\
\hline
\end{tabular}




\section{Resource use efficiency}

The model specification test to select the most appropriate functional form for the study is shown in Table 2. The null hypothesis that the CobbDouglas production function is best fit for the data is rejected at $1 \%$ significant level. Similarly, the proposition that the traditional production function best described the data, implying that the deterministic production function is desirable is rejected at $1 \%$ significance level. Therefore, the stochastic Translog estimates were used for the calculation of marginal productivities of the inputs (Table 3).

Table 2. Model specification test

\begin{tabular}{|c|c|c|c|}
\hline No. & Null hypothesis & Statistic & Decision rule \\
\hline 1. & $\begin{array}{l}\text { Cobb-Douglas is best fit for the data } \\
\qquad \mathrm{H}_{0}: \beta_{\mathrm{jk}}=0\end{array}$ & $\begin{array}{l}\text { Likelihood-ratio Chi-square } \\
43.22^{* * *} \\
(0.0029)\end{array}$ & $\begin{array}{l}\text { Reject null } \\
\text { hypothesis at } 1 \%\end{array}$ \\
\hline 2. & $\begin{array}{l}\text { Traditional production function fits the data } \\
\qquad \mathrm{H}_{0}: \mathrm{U}_{1}=0\end{array}$ & $\begin{array}{l}\text { Likelihood-ratio Chi-square } \\
28.71^{* * *} \\
(0.0000)\end{array}$ & $\begin{array}{l}\text { Reject null } \\
\text { hypothesis at } 1 \%\end{array}$ \\
\hline
\end{tabular}

Note: $* * * * *$ and $*$ denote statistical significance at the $1 \%, 5 \%$ and $10 \%$ level respectively

Table 3. Maximum likelihood estimates of the Stochastic Translog production model

\begin{tabular}{|c|c|c|c|c|c|}
\hline Variable & Parameters & Coefficients & Standard error & z-statistic & $P>|z|$ \\
\hline Cons & $\beta_{0}$ & 0.165 & $0.090 *$ & 1.840 & 0.066 \\
\hline LnSeed $(\mathrm{kg})$ & $\beta_{1}$ & 0.211 & $0.096^{* *}$ & 2.190 & 0.028 \\
\hline $\operatorname{LnIno}(\mathrm{g})$ & $\beta_{2}$ & -0.100 & 0.092 & -1.090 & 0.275 \\
\hline LnLabor(man-days) & $\beta_{3}$ & 0.193 & $0.085^{* *}$ & 2.280 & 0.022 \\
\hline LnFert $(\mathrm{kg})$ & $\beta_{4}$ & -0.154 & $0.093^{*}$ & -1.660 & 0.098 \\
\hline LnAgro (L) & $\beta_{5}$ & 0.058 & 0.075 & 0.770 & 0.439 \\
\hline LnFsize (ha) & $\beta_{6}$ & 0.679 & $0.132 * * *$ & 5.140 & 0.000 \\
\hline $0.5(\mathrm{LnSeed})^{2}$ & $\beta_{7}$ & -1.738 & $0.695 * * *$ & -3.290 & 0.012 \\
\hline $0.5(\text { LnIno })^{2}$ & $\beta_{8}$ & 0.205 & 0.182 & -2.500 & 0.261 \\
\hline $0.5{\text { (LnLabor })^{2}}^{2}$ & $\beta_{9}$ & 0.442 & 0.470 & 1.120 & 0.346 \\
\hline $0.5(\text { LnFert })^{2}$ & $\beta_{10}$ & 0.263 & $0.133 * *$ & 1.970 & 0.048 \\
\hline $0.5{\text { (LnAgro })^{2}}^{2}$ & $\beta_{11}$ & 0.471 & 0.485 & 0.970 & 0.331 \\
\hline $0.5(\text { LnFsize })^{2}$ & $\beta_{12}$ & -3.338 & $1.015 * * *$ & 0.940 & 0.001 \\
\hline LnSeed* LnIno & $\beta_{13}$ & 0.050 & 0.100 & 0.490 & 0.621 \\
\hline LnSeed*LnLabor & $\beta_{14}$ & -1.083 & $0.590 *$ & -1.840 & 0.066 \\
\hline LnSeed*LnFert & $\beta_{15}$ & -0.387 & $0.197 * *$ & -1.970 & 0.049 \\
\hline LnSeed*LnAgro & $\beta_{16}$ & -0.324 & 0.396 & -0.820 & 0.412 \\
\hline Lnseed*LnFsize & $\beta_{17}$ & 2.622 & $0.656 * * *$ & 4.000 & 0.000 \\
\hline LnIno*LnLabor & $\beta_{18}$ & -0.170 & $0.104^{*}$ & -1.640 & 0.102 \\
\hline LnIno*LnFert & $\beta_{19}$ & 0.027 & 0.029 & 0.930 & 0.353 \\
\hline LnIno*LnAgro & $\beta_{20}$ & 0.001 & 0.060 & 0.020 & 0.985 \\
\hline LnIno*LnFsize & $\beta_{21}$ & -0.060 & 0.134 & -0.450 & 0.655 \\
\hline LnLabor*LnFert & $\beta_{22}$ & 0.032 & 0.118 & 0.270 & 0.788 \\
\hline LnLabor*LnAgro & $\beta_{23}$ & 0.000 & 0.304 & 0.000 & 0.999 \\
\hline LnLabor*LnFsize & $\beta_{24}$ & 0.586 & 0.722 & 0.810 & 0.416 \\
\hline LnFer*LnAgro & $\beta_{25}$ & 0.032 & 0.084 & 0.390 & 0.698 \\
\hline LnFert*LnFsize & $\beta_{26}$ & 0.125 & 0.164 & 0.760 & 0.447 \\
\hline LnFsizeLnAgro & $\beta_{27}$ & 0.192 & 0.486 & 0.400 & 0.692 \\
\hline
\end{tabular}

Sigma v $\left(\sigma_{V}\right), 0.086(0.018)$; sigma u $\left(\sigma_{u}\right), 0.362(0.026) ; \operatorname{sigma}^{2}\left(\sigma^{2}\right), 0.139(0.017)$

lambda $(\lambda), 4.221(0.094)$; Gamma $(\gamma), 0.943$; Log-likelihood, 26.275; Wald Chi-square, 836.90***

Note: $* * *, * *, *$ denote statistical significance at the $1 \%, 5 \%$ and $10 \%$ level respectively; *Figures in bracket are Standard errors 
The gamma $(\gamma)$ value calculated for the respondents was 0.943 . The closeness of this value to one (1) and the high Lambda $(\lambda)$ value imply inefficiencies in soya bean production in the study area. This also makes the stochastic frontier model appropriate for the study (Piesse and Thirtle, 2000; Wongnaa and Awunyo-Vitor, 2018). The results therefore suggest that about $0.1 \%$ of the variations in maize outputs for the maize farmers are attributed to the presence of random shocks outside the control of the farmer. Examples of these random shocks include bad weather, diseases, topology, bushfires as well as statistical errors in measuring data. The values of $\lambda(\mathrm{p}<0.1)$ and $\sigma^{2}(\mathrm{p}<0.05)$ indicate a good fit of the model and correctness of the specified distributional assumptions.

The estimated coefficients of soya bean seeds, labor and farm size were significant and positively related to soya bean output even though fertilizer input was surprisingly significantly and negatively related to the output of soya bean. An increase in the quantities of each seed, labor and farm size by $1 \%$ will lead to a $0.211 \%$, $0.193 \%$ and $0.679 \%$ increase in the output of soya bean respectively. Conversely, soya bean output decreased with a $1 \%$ increase in quantity of fertilizer. Soya bean farmers might be using the wrong fertilizer with high nitrogen content. This is because soya bean is a legume and has nitrogen fixing bacteria that fix nitrogen into the soil where it is grown and therefore, fertilizer application will increase vegetative growth at the expense of reproductive growth. This will reduce soya bean yield and consequently, given that soya bean is a major source of plant protein and a source of income for people living in Upper West region of Ghana, it will lead to food insecurity and poverty. However, if farmers rather used fertilizers rich in phosphorous, which is required for root development and seed development, yield will be higher and food insecurity and poverty will be reduced.

\section{Production elasticities and ratio of MVP to MFC}

The estimated resource use efficiency $(r)$, that is, ratios of MVP to MFC, of all the inputs was positive and above unity except labor, which was below 1 confirming the presence of resourceuse imbalances with respect to technologies available to farmers (Table 4). The results imply that farm size, quantity of inoculants, volume of agrochemical, fertilizer and seed were underutilized. Soya bean farmers could, therefore, increase yield and raise profit if these resources are increased. Meanwhile, labor was overutilized and farmers could increase yield while using less of this resource. The result however, shows negative elasticities for fertilizer and inoculants, implying an increase in these inputs could reduce output, a situation that could lead to food insecurity and poverty among the farmers. Given the market prices of output and inputs, these inputs except labor are underutilized and must be increased for profit maximization since that is the major aim of farmers.

Table 4. Input elasticities, ratio of MVP to MFC

\begin{tabular}{lcrrrr}
\hline \multicolumn{1}{c}{ Variable } & Elasticity & \multicolumn{1}{c}{ MPP } & $\begin{array}{c}\text { MVP } \\
\left(\mathrm{MPP}_{\mathrm{x}} \cdot \mathrm{P}_{\mathrm{y}}\right)\end{array}$ & $\mathrm{MFC}$ & $\mathrm{r}\left(\frac{\mathrm{MVP}}{\mathrm{MFC}}\right)$ \\
\hline Land (farm size) (ha) & 0.679 & 805.800 & $1,305.54$ & 243.75 & 5.356 \\
Fertilizer (kg) & -0.154 & 6.600 & 10.69 & 1.74 & 6.145 \\
Inoculants (g) & -0.100 & 1.302 & 2.11 & 0.15 & 14.060 \\
Agrochemicals (L) & 0.058 & 14.202 & 23.01 & 16.45 & 1.399 \\
Seed (kg) & 0.211 & 5.319 & 8.62 & 1.94 & 4.441 \\
Labor (man-days) & 0.193 & 4.519 & 7.32 & 8.91 & 0.822 \\
Elasticity of production (EP) & 0.890 & & & & \\
\hline
\end{tabular}

Lower quantities of resources and technologies applied may be the underlying factor for resource allocation, as focus group discussions with respondents show that farmers primarily used saved soya bean grains for planting at a seeding rate of $33.90 \mathrm{~kg} \mathrm{ha}^{-1}$ against the recommended 70 $\mathrm{kg} \mathrm{ha}^{-1}$ of certified seeds (Singh, 2018). Further, the major inputs including fertilizer (Ammonium Sulphate) and inoculants are applied at rate of $19.94 \mathrm{~kg} \mathrm{ha}^{-1}$ (against recommended rate, $100 \mathrm{~kg}$ ) and $65.65 \mathrm{~g} \mathrm{ha}^{-1}$ (against the recommended rate, $500 \mathrm{~g}$ ) (Singh, 2018), respectively, tend to justify farmer's underinvestment in resources and technologies. The lower applications of fertilizer 
may be linked to farmer's perception that soya bean does not required inorganic fertilization for production. Even though fertilizer is negatively related to soya bean output in this study, with the right type of fertilizer (rich in phosphorous), fertilizer usage must be increased. Interviews with farmers also reveal that the biological nature of inoculant demands for controlled environment and temperature that complicates handling, usage and storage for farmers, hence might reduce the amount and efficacy of the rhizobium bacteria for effective inoculation on the field. Moreover, the capital base of soya bean farmers is low and hence, they might not be able to afford the expensive improved seeds, fertilizers, agrochemicals and inoculants confirming resource underinvestments.

The study also shows $80 \%$ of female soya bean farmers who constantly face constraints in accessing productive assets such as land under the patrilineal inheritance system of Upper West region, thus signifying under allocation of land for soya bean production in the area. The average landholdings are $0.72 \mathrm{ha}$, which are below the 1 ha to 2 ha for a smallholder farmer. On the other hand, reasons for the overutilization of labor for soya bean production could be attributed to the larger farm household sizes of the respondents. This is so because in smallholder farming systems, especially in northern Ghana, family size denotes labor availability for agricultural production activities. The overall elasticity of 0.89 implies decreasing returns to scale, which justifies that soya bean farmers are within the economic region of production (stage II) and must use more inputs until maximum profit is achieved.

\section{Adjustment for resource use efficiency}

To ascertain the percentage deviation from optimal resource use level, the percentage divergence was calculated (Table 5). For optimal utilization of resources, farm land requires $81 \%$ upward adjustment, while $93 \%$ is demanded for optimal use of inoculants. Similarly, 29\% upward adjustment is needed for efficient use of agrochemicals, $84 \%$ for fertilizers and $77 \%$ for seeds for maximum production. Conversely, labor needs to be adjusted downwards by $22 \%$. The data indicate that soya bean farmers must put in much effort to close the gap for optimum resource use for improved production. The result compares well with a study by Awunyo-Vitor et al. (2016) on resource use efficiency among maize farmers in Ghana.

Table 5. Adjustments in MVPs for optimal resource use (\% divergence)

\begin{tabular}{lcc}
\multicolumn{1}{c}{ Variable } & Efficiency gap & \% divergence from optimal levels \\
\hline Land (farm size) (ha) & $1,061.79$ & 81 \\
Fertilizers (kg) & 8.95 & 84 \\
Inoculants (g) & 1.96 & 93 \\
Agrochemicals (L) & 6.56 & 29 \\
Seeds (kg) & 6.68 & 77 \\
Labor (man-days) & 1.59 & 22 \\
\hline
\end{tabular}

\section{Constraints to soya bean production}

Even though the level of agreement (Kendal's $\mathrm{W}=14 \%$ ) among farmers on constraints affecting soya bean production is low, it is however significant at $1 \%$ with $\chi^{2}=336.64$ which implies that we reject the null hypothesis that farmers do not agree on their ranking of production constraints in favor of the alternative hypothesis (Table 6). The most important constraint is access to soya bean threshers with a mean rank of 4.08. Interview with farmers indicates that threshers, specifically for soya bean are inadequate and hence, farmers rely on hiring multipurpose threshers for services. Meanwhile, the competition for these multipurpose threshers is high for threshing maize that fetches higher returns than soya bean. Therefore, private thresher operators feel reluctant to offer services for soya bean threshing. The finding is similar to the result of study by Shalma (2014), which reported that soya bean farmers in Kaduna State, Nigeria ranked the absence of threshing machine as one of the most pressing constraints.

The $3^{\text {rd }}$ most limiting constraint is access to tractor services after credit provision $\left(2^{\text {nd }}\right)$. Land is ranked the least constraint because its inheritance is based on family lineage that is often controlled by men who decide when and how the land should be used. Given the high proportion of female farmers in soya bean production, this 
finding is a bit surprising since women will have to seek permission from their husbands for land use. However, as a collective household resource, land is readily available to women for soya bean farming so long as male household members do not have alternative use for the same piece of land. Mbanya (2011) also reported similar findings in Northern region of Ghana.

Table 6. Coefficient of concordance (W) rank of soya bean production constraints

\begin{tabular}{|c|c|c|c|c|c|c|c|c|}
\hline \multirow{3}{*}{ Variable } & \multicolumn{8}{|c|}{ Districts } \\
\hline & \multicolumn{2}{|c|}{ Sissala West } & \multicolumn{2}{|c|}{ Wa East } & \multicolumn{2}{|c|}{ DBI } & \multicolumn{2}{|c|}{ All districts } \\
\hline & $\begin{array}{c}\text { Mean } \\
\text { rank }\end{array}$ & Position & $\begin{array}{c}\text { Mean } \\
\text { rank }\end{array}$ & Position & $\begin{array}{c}\text { Mean } \\
\text { rank }\end{array}$ & Position & $\begin{array}{c}\text { Mean } \\
\text { rank }\end{array}$ & Position \\
\hline Tractor services & 3.96 & 1 & 4.11 & 4 & 3.22 & 3 & 4.08 & 3 \\
\hline Lack of threshers & 4.03 & 2 & 4.54 & 2 & 3.59 & 2 & 4.22 & 1 \\
\hline Low price of output & 4.07 & 3 & 4.69 & 3 & 4.81 & 4 & 4.49 & 4 \\
\hline High cost of inputs & 4.39 & 4 & 4.79 & 6 & 5.42 & 5 & 4.68 & 5 \\
\hline Access to credit & 5.13 & 5 & 5.24 & 1 & 5.63 & 1 & 5.26 & 2 \\
\hline Lack of market & 5.35 & 6 & 5.85 & 5 & 6.12 & 7 & 5.56 & 6 \\
\hline $\begin{array}{l}\text { Inadequate technical } \\
\text { information on soya bean } \\
\text { cultivation }\end{array}$ & 6.52 & 7 & 6.22 & 9 & 6.20 & 9 & 6.30 & 8 \\
\hline Pest and diseases & 6.53 & 8 & 6.44 & 7 & 6.51 & 6 & 6.50 & 7 \\
\hline Access to extension service & 7.23 & 9 & 6.45 & 8 & 6.55 & 8 & 6.75 & 9 \\
\hline Land & 7.80 & 10 & 6.69 & 10 & 6.94 & 10 & 7.16 & 10 \\
\hline Kendell's W & \multicolumn{2}{|r|}{0.223} & \multicolumn{2}{|c|}{0.096} & \multicolumn{2}{|r|}{0.174} & \multicolumn{2}{|r|}{0.138} \\
\hline$\chi^{2}$ & \multirow{2}{*}{\multicolumn{2}{|c|}{$\begin{array}{c}196.32 \\
9\end{array}$}} & \multirow{2}{*}{\multicolumn{2}{|c|}{$\begin{array}{c}81.47 \\
9\end{array}$}} & \multirow{2}{*}{\multicolumn{2}{|c|}{$\begin{array}{c}123.98 \\
0\end{array}$}} & \multicolumn{2}{|c|}{336.64} \\
\hline $\mathrm{DF}$ & & & & & $\begin{array}{r}9 \\
70\end{array}$ & & \multicolumn{2}{|r|}{9} \\
\hline $\mathrm{N}$ & \multicolumn{2}{|c|}{98} & \multicolumn{2}{|c|}{94} & & 9 & & 71 \\
\hline $\mathrm{P}<$ & \multicolumn{2}{|c|}{0.000} & \multicolumn{2}{|c|}{0.000} & \multicolumn{2}{|c|}{0.000} & \multicolumn{2}{|c|}{0.000} \\
\hline
\end{tabular}

Note: $1=$ Highest constraint and $10=$ Least constraints

\section{CONCLUSIONS}

The study examines the resource use efficiency and constraints to soya bean production in Upper West region of Ghana. The results show that resources employed in soya bean production in the region are underutilized and soya bean farmers could increase yield and raise profit if farm size, quantity of inoculants, volume of agrochemical, fertilizer and seed are increased. The most important constraint to soya bean production is inadequate access to soya bean threshers. For resource use efficiency, farmers should be given financial support for their production activities and bring threshing and tractor services to their doorsteps at affordable prices.

\section{REFERENCES}

Al-hassan, R. M. \& Diao, X. (2007). Regional disparities in Ghana: policy options and public investment implications. Accra, Ghana: International Food Policy Research Institute.
Retrieved from https://core.ac.uk/download/ pdf/6337671.pdf

Amaechina, E. C., \& Eboh, E. C. (2017). Resource use efficiency in rice production in the Lower Anambra irrigation project, Nigeria. Journal of Development and Agricultural Economics, 9(8), 234-242. Retrieved from https://academicjournals.org/journal/JDAE/art icle-full-text-pdf/B4F602465323

Amanor-Boadu, V., Zereyesus, Y., \& Ross, K. (2015). Agricultural production survey for the Northern Regions of Ghana: 20132014 Results. Manhattan, KS, United States: Department of Agricultural Economics 306 Waters Hall, Kansas State University. Retrieved from https://www.agmanager.info /sites/default/files/APS_Report_2016_Final. pdf

Ansah, I. G., Toatoba, J., \& Donkoh, S. A. (2016). The effect of credit constraints on crop yield: Evidence from soya bean farmers in Northern region of Ghana. Ghana Journal of Science, 
Technology and Development, 4(1), 52-67. Retrieved from https://gjstd.org/index.php/GJ STD/article/view/78

Aryeetey, E., \& Mckay, A. (2004). Operationalizing pro-poor growth: Ghana Case Study. London: DFID. Retrieved from https:// www.researchgate.net/publication/228638321 _Operationalizing_Pro-Poor_Growth_Ghana_ Case_Study

Avea, A. D., Zhu, J., Tian, X., Baležentis, T., Li, T., Rickaille, M., \& Funsani, W. (2016). Do NGOs and development agencies contribute to sustainability of smallholder soybean farmers in Northern Ghana - a stochastic production frontier approach. Sustainability, 8(5), 465. https://doi.org/10.3390/su8050465

Awunyo-vitor, D., Bakang, J., \& Cofie, S. (2013). Estimation of farm level technical efficiency of small-scale cowpea production in Ghana. American-Eurasian Journal of Agricultural and Environmental Science, 13(8), 10801087. Retrieved from https://www.idosi.org/ aejaes/jaes13(8)13/9.pdf

Awunyo-Vitor, D., Wongnaa, C. A., \& Aidoo, R. (2016). Resource use efficiency among maize farmers in Ghana. Agriculture and Food Security, 5(1), 28. https://doi.org/10.1186/s4 0066-016-0076-2

Battese, G. E., \& Coelli, T. J. (1995). A model for technical inefficiency effects in a stochastic frontier production function for panel data. Empirical Economics, 20, 325-332. https:// doi.org/10.1007/BF01205442

Chianu, J. N., Ohiokpehai, O., Vanlauwe, B., Adesina, A., De Groote, H., \& Sanginga, N. (2009). Promoting a Versatile but yet minor crop: Soybean in the farming systems of Kenya. Journal of Sustainable Development in Africa, 10(4), 324-344. Retrieved from https://www.researchgate.net/publication/235 733212_Promoting_a_Versatile_but_yet_Min or_Crop_Soybean_in_the_Farming_Systems_ of_Kenya

Dogbe, W., Etwire, P. M., Martey, E., Etwire, J. C., Baba, I. I., \& Siise, A. (2013). Economics of soybean production: evidence from Saboba and Chereponi districts of Northern region of Ghana. Journal of Agricultural Science, 5(12), 38-46. https://doi.org/10.5539/jas.v5n12p38
FAOSTAT. (2018). Ghana. Food and Agriculture Organization of the United Nations. Retrieved from http://www.fao.org/faostat/en/\#country/ 81

Fasasi, A. R. (2006). Resource use efficiency in yam production in Ondo State. Nigeria. Agricultural Journal, 1(2), 36-40. Retrieved from https://medwelljournals.com/abstract/? doi=aj.2006.36.40

Giller, K. E., Murwira, M. S., Dhliwayo, D. K. C., Mafongoya, P. L., \& Mpepereki, S. (2011). Soyabeans and sustainable agriculture in Southern Africa. International Journal of Agricultural Sustainability, 9(1), 50-58. https://doi.org/10.3763/ijas.2010.0548

Goni, M., Umar, A. S. S., \& Usman, S. (2013). Analysis of resource-use efficiency in dry season vegetable production in Jere, Borno State, Nigeria. Journal of Biology, Agriculture and Healthcare, 3(19), 18-23. Retrieved from https://www.iiste.org/Journals/index.php/JBA H/article/view/9770

Kay, R. D. (1981). Farm management planning, control and implementation. New York: McGraw-Hill Book Co.

Khalid, S. M. N., \& Sherzad, S. (2019). Agricultural extension manual for extension workers. Apia: Sub Regional Office for the Pacific (SAP), Food and Agriculture Organization of the United Nations (FAO). Retrieved from http://www.fao.org/3/ca5007 en/ca5007en.pdf

Latruffe, L. (2010). Competitiveness, productivity and efficiency in the agricultural and agri-food sectors. OECD Food, Agriculture and Fisheries Papers, No. 30, Paris: OECD Publishing. http://dx.doi.org/ $10.1787 / 5 \mathrm{~km} 91 \mathrm{nkdt6d6}$-en

Maikasuwa, M. A., \& Ala, A. L. (2012). Determination of profitability and resourceuse efficiency of yam production by women in Bosso Local Government Area of Niger State, Nigeria. European Scientific Journal, 9(16), 198-205. Retrieved from https://eujournal. org/index.php/esj/article/view/1143

Majumder, M. K., Mozumdar, L., \& Roy, P. (2009). Productivity and resource use efficiency of boro rice production. Journal of the Bangladesh Agricultural University, 
7(2), 247-252. https://doi.org/10.3329/jbau. v7i2.4730

Mbanya, W. (2011). Assessment of the constraints in soybean production: A case of Northern Region, Ghana. Journal of Developments in Sustainable Agriculture, 6(2), 199-214 https://doi.org/10.11178/jdsa.6. 199

Miah, M. A. K., Alam, A. K. M. A., \& Rahman, A. H. M. A. (2006). Impact of agricultural credit on MV Boro Rice Cultivation in Bangladesh. Journal of Agriculture \& Rural Development, 4(1), 161-168. https://doi.org/ 10.3329/jard.v4i1.784

MoFA. (2011). Agriculture in Ghana: Facts and Figures (2010). Accra, Ghana: Statistics, Research and Information Directorate (SRID), Ministry of Food and Agriculture. Retrieved from https://new-ndpc-static1.s3.amazonaws. com/CACHES/PUBLICATIONS/2016/04/16/ AGRICULTURE-IN-GHANA-Facts+and+ Figures-2010.pdf

Mpepereki, S., Javaheri, F., Davis, P., \& Giller, K. E. (2000). Soyabeans and sustainable agriculture Promiscuous soyabeans in southern Africa. Field Crops Research, 65 (2-3), 137-149. https://doi.org/10.1016/S03 78-4290(99)00083-0

Mugabo, J., Tollens, E., Chianu, J., Obi, A., \& Vanlauwe, B. (2014). Resource use efficiency in soya bean production in Rwanda. Journal of Economics and Sustainable Development, 5(6), 116-122. Retrieved from https://www. iiste.org/Journals/index.php/JEDS/article/vie $\mathrm{w} / 11941$

Nimoh, F., Tham-Agyekum, E. K., \& Kwaku Nyarko, P. (2012). Resource use efficiency in rice production: the Case of Kpong Irrigation Project in the Dangme West District of Ghana. International Journal of Agriculture and Forestry, 2(1), 35-40. https://doi.org/10.5923 /j.ijaf.20120201.06

Obasi, M. O., Obinne, C. P. O., \& Oboh, V. U. (2000). Resource-use efficiency in soybean production in Benue State, Nigeria. Journal of Agriculture Technology \& Education, 5(1/2), 16-20. Retrieved from https://www.cabdirect. org/cabdirect/abstract/20013031043

Ohajianya, D. O. (2006). Resource use efficiency of land owners and tenants in food crop production in Imo State Nigeria. Journal of Sustainable Tropical Agricultural Research, 17, 26-30. Retrieved from https://scholar. google.co.id/scholar?cluster $=6991520925600$ $47370 \& \mathrm{hl}=\mathrm{id} \&$ as_sdt $=2005 \&$ sciodt $=0,5 \&$ aut huser $=3$

Oyekunle, O., Onifade, O. T., Ayanda, I. F., Amusat, A. S., \& Bolarinwa, K. K. (2014). Constraints associated with cultivation and utilization of soyabean by farmers in Ogun State, Nigeria. Journal of Biology, Agriculture and Healthcare, 4(12), 48-53. Retrieved from https://www.iiste.org/Journals/index.php/JBA H/article/view/12944

Piesse, J. \& Thirtle, C. (2000). A stochastic frontier approach to firm level efficiency, technological change and productivity during the early transition in Hungary. Journal of Comparative Economics, 28(3), 473-501. https://doi.org/10.1006/jcec.2000.1672

Salisu, A. B., Shakuga, J. E., \& Dagi, M. B. (2015). Profitability analysis of small scale egg production in Bauchi Metropolis, Bauchi State, Nigeria. Agriculture: A Review Focus for Economic Development in Nigeria. Proceedings of the 29th Annual Conference of Farm Management Association of Nigeria, Dutse 2015, 524. https://doi.org/10.9790/23 80-1001015965

Sani, A., Yakubu, A., \& Bello, H. (2011). Resource-Use efficiency in rice production under small scale irrigation in Bunkure Local Government Area of Kano State. Nigerian Journal of Basic and Applied Sciences, 18(2), 292-296. https://doi.org/10.4314/njbas.v18i2. 64344

Seyoum, E. T., Battese, G. E., \& Fleming, E. M. (1998). Technical efficiency and productivity of maize producers in eastern Ethiopia: A study of farmers within and outside the Sasakawa-Global 2000 project. Agricultural Economics, 19(3), 341-348. https://doi.org/ 10.1016/S0169-5150(98)00037-1

Shalma, H. J. (2014). Economic analysis of soya bean production under Sasakawa Global 2000 Project in Kaduna State, Nigeria [Unpublished Master Thesis]. Zaria, Nigeria: Ahmadu Bello University. Retrieved from https://scholar.google.co.id/scholar?cluster=6 
$862182125931962858 \& h l=i d \& a s \_s d t=2005 \&$ sciodt $=0,5 \&$ authuser $=3$

Shehu, U.A., Ibrahim, A., Hassan, T., \& Bello, M. (2017). Analysis of resource use efficiency in small-scale maize production in TafawaBalewa local Government of Bauchi State Nigeria. IOSR Journal of Agriculture and Veterinary Science, 10(2), 29-35. Retrieved from https://www.iosrjournals.org/iosr-javs/ papers/Vol10-issue1/Version-1/K1001015965 .pdf

Singh, C. (2018). No Title. Retrieved from http://megapib.nic.in/ppsoyabean.htm

SRID. (2013). Production Estimates. National Information Technology Agency (NITA), Government of Ghana. Retrieved from https:// data.gov.gh/dataset/crop-production-estimates -major-regions-ghana/resource/eae $1 \mathrm{a} 05 \mathrm{~b}-\mathrm{a} 13$ e-40e7-a646-6c89b01262a8

Tambo, J. A., \& Gbemu, T. (2010). Resourceuse efficiency in tomato production in the Dangme West District, Ghana. In: Conference on International Research on Food Security, Natural Resource Management and Rural Development. Tropentag. ETH Zurich. Retrieved from https://moam.info/ resource-use-efficiency-in-tomato-production -in-the-tropentag_59b9bca61723dddd8c6ad5f4 2.html

Tirlapur, L. N., \& Mundinamani, S. M. (2015). Resource use efficiency in cultivation of major crops of Dharwad district. Agriculture Update, 10(2), 93-99. https://doi.org/10.15740/has/au/ $10.2 / 93-99$

Upev, S. K., Haruna, L., \& Giroh, D. Y. (2016). Analysis of resource use efficiency among soybean (Glycine max) farmers in Gboko local government area of Benue state, Nigeria. Global Journal of Agricultural Sciences, 15(1), 57-63. https://doi.org/10.4314/gjass. v15i1.9

Wongnaa, C. A., \& Awunyo-Vitor, D. (2018). Achieving sustainable development goals on no poverty and zero hunger: Does technical efficiency of Ghana's maize farmers matter? Agriculture \& Food Security, 7(1), 71. https:// doi.org/10.1186/s40066-018-0223-z

Wongnaa, C. A., \& Ofori, D. (2012). Resourceuse efficiency in cashew production in Wenchi Municipality, Ghana. Agris On-Line Papers in Economics and Informatics, 4(2), 73-80. http://dx.doi.org/10.22004/ag.econ.131364

Yamane, T. (1967). Elementary sampling theory. Upper Saddle River, New Jersey, United States: Prentice-Hall. 